\title{
Study effect of plant extraction for Cuscuta europaea (Dodder) against two species of bacteria Staphylococcus aureus and Escherichia coli
}

\author{
Jasim A. Abdullah, ${ }^{*}$ Amer Ali Hammadi, Russell Hakem, Zahra Hatef and Noor Hussein
}

Department of Clinical Laboratories, College of Applied Medical Sciences, University of Karbala, Karbala, Iraq.

Corresponding author: Jasim A. Abdullah (email: Jasim.abdulabbas@gmail.com).

(Submitted: 28 July 2016 - Revised version received: 22 August 2016 - Accepted: 30 August 2016 - Published online: 26 December 2016)

\begin{abstract}
Objective: The goal of this study is focused on the effect of crude extract of Cuscuta europaea plant and compared with Amoxicillin drug, and then we showed these effects on Staphylococcus aureus and Escherichia coli. The analysis shows that the side effect of drug is high on human. We try to find the alternative antimicrobial to treat the bacterial infection.

This study focuses on two treatments to inhibit the growth of two species of bacteria that are Amoxicillin as drug and Cuscuta eurooaea as extract until show the activity antimicrobial of these amount on bacteria.

Methods: The current study included Cuscuta europaea as extract and Amoxicillin as drug and two species of the bacteria Staphylococcus aureus and Escherichia coli. This study has been investigated to show the antimicrobial activity of plant extract and drug on the bacteria. Results: During this study, the results reveal that the activity of antimicrobial of extract plant was higher than Amoxicillin on Staphylococcus aureus but the both Amoxicillin and extract did not have any effect on Escherichia coli in each concentration. And we showed the best result recorded in concentration $20 \mathrm{mg} / \mathrm{ml}$ of extract plant when compared with amoxicillin drug.

Conclusion: There are no significant differences between the concentration of plant extract of bacteria, and we showed the plant extract have a high effect on gram positive bacteria but do not have any effect on gram negative bacteria.

Keywords bacteria, amoxicillin, dodder, antimicrobial activity
\end{abstract}

\section{Introduction}

Pathogenic bacteria have been always considered as a major cause of morbidity and mortality in human. Even though pharmaceutical companies have produced a number of new antibacterial drugs in the last year, the global emergence of multi-drug resistant bacteria is increasingly limiting the effectiveness of current drug and significantly causing treatment failure; Due to the increase of resistance of antibiotics, there is a pressing need to develop new and innovative antimicrobial agent. The potential source of new agent plants that have long been investigated contain many bioactive compounds that can be of interest in therapeutic because of their low toxicity.

\section{Amoxicillin}

This is a penicillin antibiotic. It is used to treat certain kinds of bacterial infection. It will not work for colds, flu, or other viral infection. This drug also comes in other forms including oral capsules, oral suspension and oral table used for bacterial infection such as some respiratory infection, infection of the urine, ear infection and dental abscesses. It works by killing the bacteria causing the infection, and sometimes used to get rid of Helicobacter pylori. This is the bacterium believed to cause stomach ulcers and works by inhibiting the synthesis of the bacterial cell wall. This means that it stops any cross linkage that would normally occur between the linear peptidoglycan polymer chains that compose that large component of the cell wall. ${ }^{1}$

\section{Singular bacterium}

This microscopic single-cell (unicellular) life form that exists practically everywhere on the earth, and is simpler than the cells of animals, fungi, and plants. It is of about three million species of bacteria believed to exist, only about 4000 are known and are divided into general groups according to their shape. ${ }^{2}$

\section{Staphylococcus spp}

This is a genus of Gram positive bacteria. Under the microscope, they appear round (cocci) and form in grape-like cluster. ${ }^{2}$ The staphylococcus genus includes at least 40 species. Nine have two subspecies, one has four subspecies. ${ }^{3}$ Most are harmless and reside normally on the skin and mucous membranes of humans and other organisms, and found worldwide. They are a small component of soil microbial flora, ${ }^{4}$ and are the most co mmon cause of localized suppurating infection; pathogenic species include: Staphylococcus aureus, Staphylococcus epidermidis, Staphylococcus saprophyticus. S. aureus strain carries on the skin, nose and pharynx as harmless commensal bacteria. Strains of staphylococcus are known to enter through the breaks in the skin to cause localized infection or spread via blood to cause more generalized infection like that of the blood (sepsis), bone (osteomyelitis), brain (meningitis), lungs (pneumonia) etc., individuals with a compromised $i$ mmune system are particularly vulnerable, etc. ${ }^{5}$

\section{Escherichia coli}

This is a Gram-negative, facultative anaerobic, rod-shaped bacterium of the genus Escherichia coli that is co mmonly found in the lower intestine of warm-blooded organisms endotherms, ${ }^{6}$ Most E. coli strains are harmless, but some serotypes can cause serious food poisoning in their hosts, and are occasionally responsible for product recalls due to food contamination. ${ }^{7,8}$ The harmless strains are part of the normal flora of the Gut, and can benefit their hosts by producing vitamin $\mathrm{K} 2,{ }^{9}$ and preventing colonization of the intestine with pathogenic bacteria. ${ }^{10,11} \mathrm{E}$. coli is expelled into the environment with fecal matter. The bacterium grows massively in the fresh fecal matter under aerobic condition for 3 days. ${ }^{12}$

\section{Medical plant}

Cuscuta europaea Roxb belongs to the family Convolvulaceae (Fig. 2). It is leafless green yellowish and thread-like twinning herb. It has a weak root under the ground but only grown as a 
parasitic twin on other plants, hence, it is known as Akaswel (sky twinner) or Amarbel (immortal twin); in English it is known as Dodder. The plant is bitter acrid and hence useful in aphrodisiac alternative and the bilious disorder (Fig. 1). Therefore, seeds are used as carminative purgative, and the juice of the plant is used as anthelmintics to purify the blood, however, fruit decoction is used in cough and fever and the stem is useful in constipation, flatulence, liver complaints. ${ }^{13}$

\section{Plant Extraction}

Plant remains the most important source of natural drug, more than $30 \%$ of prescription drugs are natural products, more than $60 \%$ of anticancer and anti-infective drugs are natural product. ${ }^{13}$

\section{Properties of good solvent in plant extraction}

- Low toxicity

- Ease of evaporation at low heat

- Promotion of rapid physiologic absorption of the extract

- Preservative action

- Inability to cause the extract to complex or dissociate

\section{Material and Methods}

\section{Preparation of plant extract}

We sterilized the blender to destroy the infectants. A small amount of plant extract was added ( $40 \mathrm{~g})$ in conical flask and then $140 \mathrm{ml}$ of ethanol alcohol was added to the plant extract. The mixture was incubated in a shaker incubator for 24 hours to dissolve the plant in alcohol and the mixture was poured in many test tubes and put the tubes in a centrifuge to separate sediment from solution and removed the sediment. The separated plant extract was poured in glass petri dishes and incubated until it gets vapor. The extracted plant pours in glass petri dishes and incubate until vapor the alcohol and accumulate the extracted plant. ${ }^{16}$

The media was prepared according to the protocol given by the company and sterilized the media in an autoclave for 15 minutes in $121^{\circ} \mathrm{C}$ and 1 psi.

\section{Dilutions preparation with E. coli and S. aureus}

We used four test tubes for each bacteria (e.g. S. aureus). $10 \mathrm{ml}$ of nutrient broth was poured in first tube and $9 \mathrm{ml}$ in remain tubes. From suspension bacteria, we took $1 \mathrm{ml}$ and put to first tube and mix. We took $1 \mathrm{ml}$ from the first tube and put in the second tube and we chose the second dilution.

The concentration of drugs and extract of the plant were prepared as five different concentrations to and put $10 \mathrm{ml}$ distilled water to each concentration $(5 \mathrm{mg} / \mathrm{ml}, 10 \mathrm{mg} / \mathrm{ml}, 15 \mathrm{mg} / \mathrm{ml}$, $20 \mathrm{mg} / \mathrm{ml}, 25 \mathrm{mg} / \mathrm{l})$. The medium was poured in a petri dish and bacteria was streaked on medium (30 petri dish to E. coli and 30 petri dishes to $S$. aureus, 3 petri dishes to each concentration).

We made holes on media. Three holes in each petri dish and poured $50 \mu \mathrm{m}$ from concentrations in the holes. The plates were incubated for 24 hours under $35-37^{\circ} \mathrm{C}$. Later, the results were recorded and calculated. We calculated zone of inhibition by ruler to drugs and to the plant extract.

\section{Preparation of MIC test}

our put (250 mg ) from extracted plant to nutrient broth and mix and prepare pure nutrient broth and we sterilize the media in autoclave in $121 \mathrm{C}$ for 15 minute after pouring the media in wells, and incubated the wells in incubator in $37^{\circ} \mathrm{C}$ for 24 hours and the results were recorded.

NOTE:- Used of ethanol because found easier to penetrate the cellular membrane to extract the intracellular ingredient (polyphenols) from the plant material.

\begin{tabular}{|c|c|}
\hline \multicolumn{2}{|c|}{ Scientific classitication } \\
\hline Kingdom: & Plantace \\
\hline (unranked): & Angiosperms \\
\hline (unranked): & Eudicots \\
\hline (unranked): & Asterids \\
\hline Order: & Solanales \\
\hline Family: & Convolvulaceae \\
\hline Genus: & Cuscuta \\
\hline Species: & C. europara \\
\hline \multicolumn{2}{|c|}{ Bincrial name } \\
\hline
\end{tabular}

Fig. 2 Plant classification.
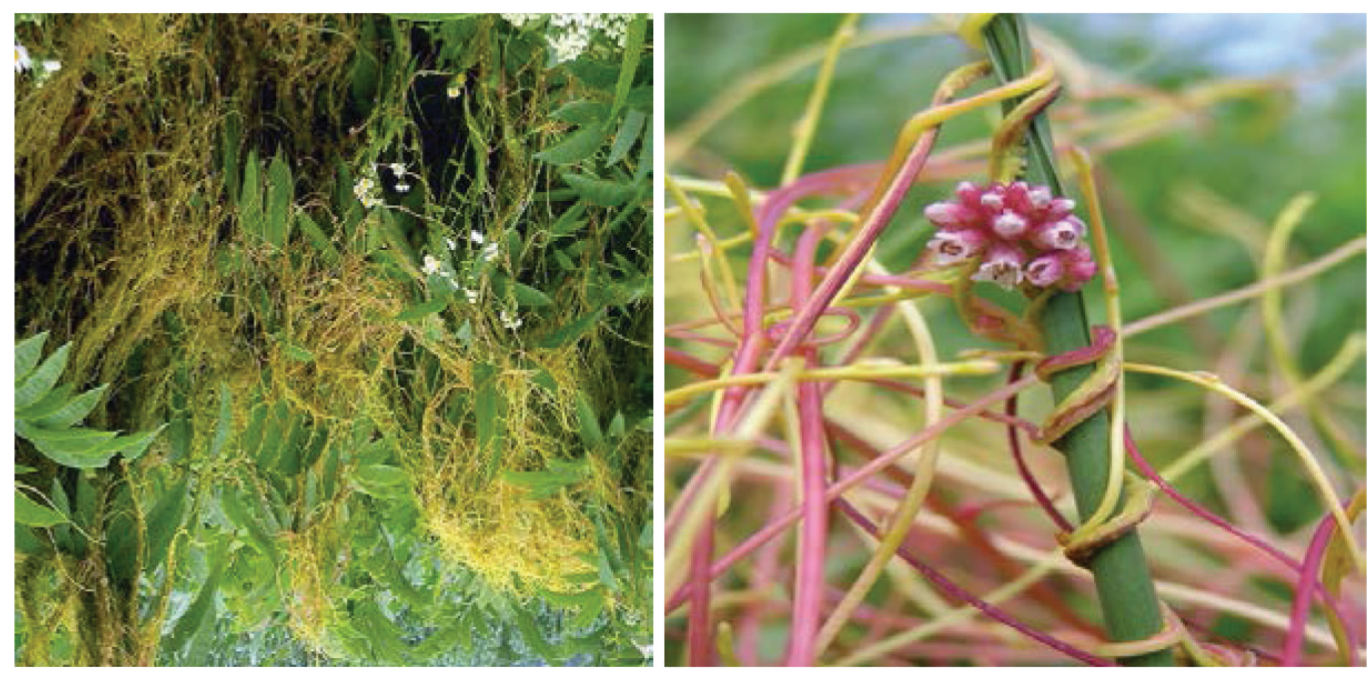

Fig. 1 Cuscuta europaea (Dodder) ${ }^{13}$ (Left) General morphology of Dodder, (Right) Tendrils of Dodder when coiled on stem of plant. 


\section{Statistical Analysis}

In statistical analysis, ANOVA table was included, and we entered the data to excel program. The data include the average of inhibition zone and the number of isolate of bacteria and other data and we used an ANOVA table to know the difference between the numbers. ${ }^{14}$

\section{Results and Discussion}

The results show that the effect of plant extract on Staphylococcus aureus as the best than Amoxicillin drugs, and did not show any significant difference between the concentration of plant extract for bacteria. Also the best result appeared in the concentration of plant extract is $20 \mathrm{mg} / \mathrm{ml}$ that is $25 \pm 1.93$, and follow $5,10,15,25 \mathrm{mg} / \mathrm{ml}$ are $24.33 \pm 3.2,24.33 \pm 1.9,22 \pm 2$ and $20.5 \pm 1.05$, respectively, and we showed the effect of plant extract and drug on E. coli bacteria also (Figs. 3, 4, 5, 6, 7, 8). The results appeared effective on plant extract on gram positive bacteria and did not show an effect on gram negative bacteria, due to the increasing prevalence of antibiotic-resistant pathogens in the hospital and homes. The deliberate search is in progress for alternative treatment to combat the further spread of antibiotic resistant-pathogen. This result is shown in Table 1.

In some study, the effect of extract plant on gram negative bacteria show more antimicrobial activity than gram positive bacteria, under many concentrations, such as 50,100, 150, 200 $\mathrm{mg} / \mathrm{ml}$. In Staphylococcus aureus, the best inhibition zone appear in $200 \mathrm{mg} / \mathrm{ml}(9.5 \mathrm{~mm})$ and the smallest inhibition zone in $50 \mathrm{mg} / \mathrm{ml}(7.1 \mathrm{~mm})$, in E. coli, the best inhibition zone appears in $200 \mathrm{mg} / \mathrm{ml}(9.7 \mathrm{~mm})$ and the smallest inhibition zone in $50 \mathrm{mg} / \mathrm{ml}(8.2 \mathrm{~mm}),{ }^{15}$ therefore, Researchers have been shown the effect of extract plant activity various from one area to another. The effect of extract plant in E. coli less than other species that found in the research, ${ }^{16}$ however, in the research, the methanol leaf extract of Momordices charantia showing

\begin{tabular}{|c|c|c|c|c|c|c|c|}
\hline \multirow{3}{*}{ No. of Bacteria } & \multicolumn{6}{|c|}{ Inhibition diameter (mm) } & \multirow{3}{*}{$\mathrm{LSD}_{0.01}$ concentration } \\
\hline & \multirow{2}{*}{$\begin{array}{c}\text { Anti con Amoxicillin } \\
(\mathrm{mg} / \mathrm{ml})\end{array}$} & \multicolumn{5}{|c|}{ Concentration of plant extract (mg/ml) } & \\
\hline & & 5 & 10 & 15 & 20 & 25 & \\
\hline Staphylococcus aureus & $17.33 \pm 0.802 \mathbf{A}$ & $24.33 \pm 3.2 \mathrm{~A}$ & $24.33 \pm 1.9 \mathbf{A}$ & $22.0 \pm 2.0 \mathrm{~A}$ & $25.0 \pm 1.93 \mathbf{A}$ & $20.5 \pm 1.05 \mathbf{A}$ & 7715 \\
\hline
\end{tabular}

*The number refer to mean of inhibition diameter $(\mathrm{mm}) \pm$ standard error. *Homologous horizontally capital letters refer to no significant differences $(P<0.01)$ between the concentration of plant extract for bacteria.
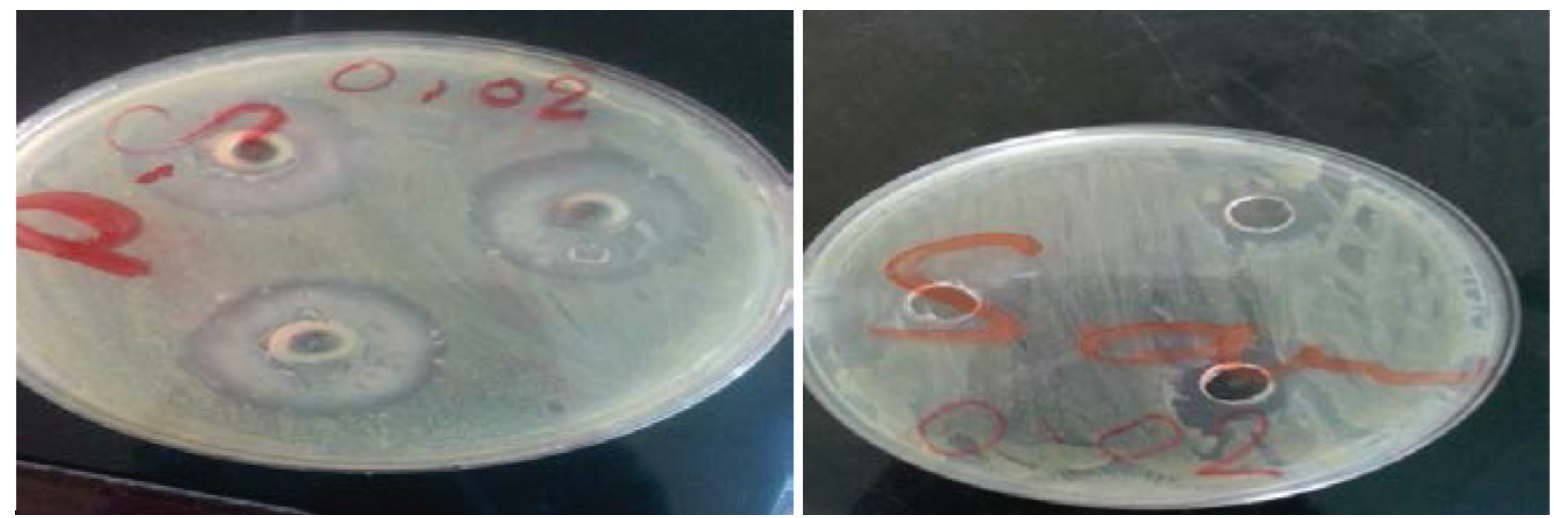

Fig. 3 S. aureus Plant conc. $20 \mathrm{mg} / \mathrm{ml}$ Control drug conc. $20 \mathrm{mg} / \mathrm{ml}$.
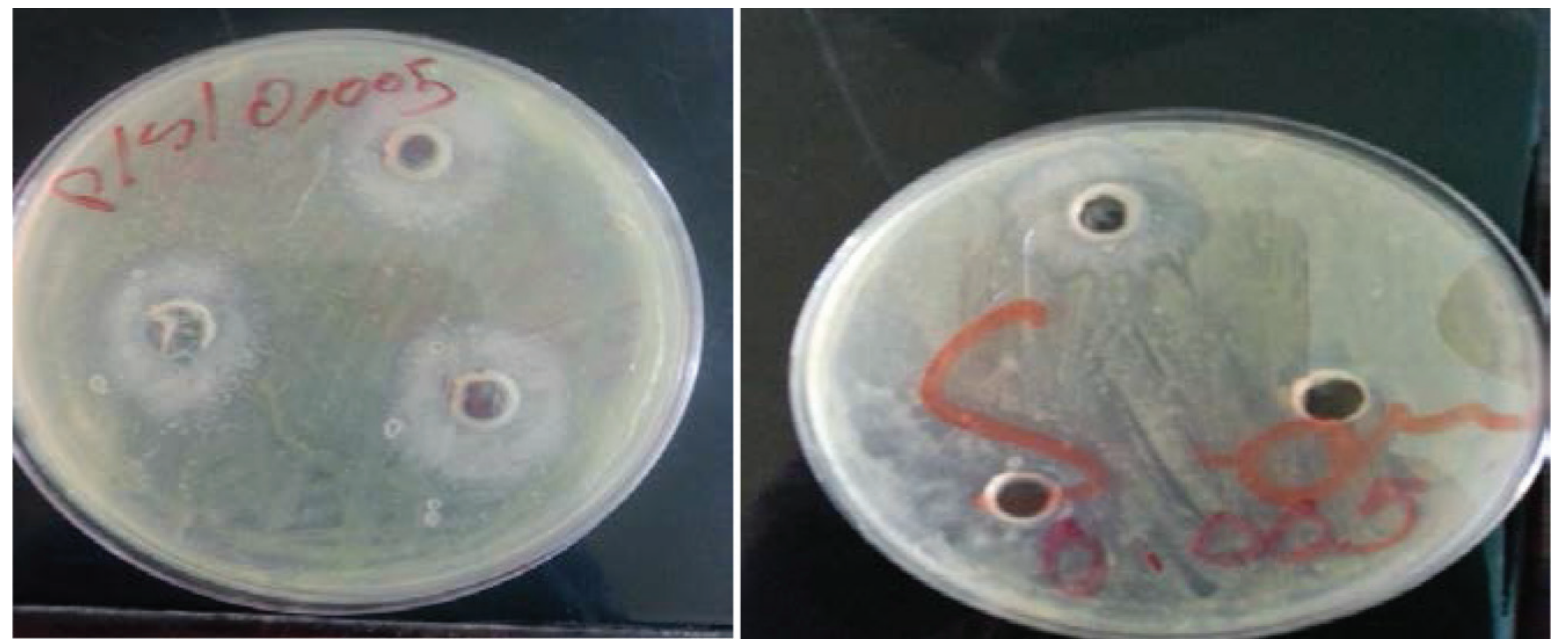

Fig. 4 S. aureus Drug conc. $5 \mathrm{mg} / \mathrm{ml}$ Plant conc. $5 \mathrm{mg} / \mathrm{ml}$. 

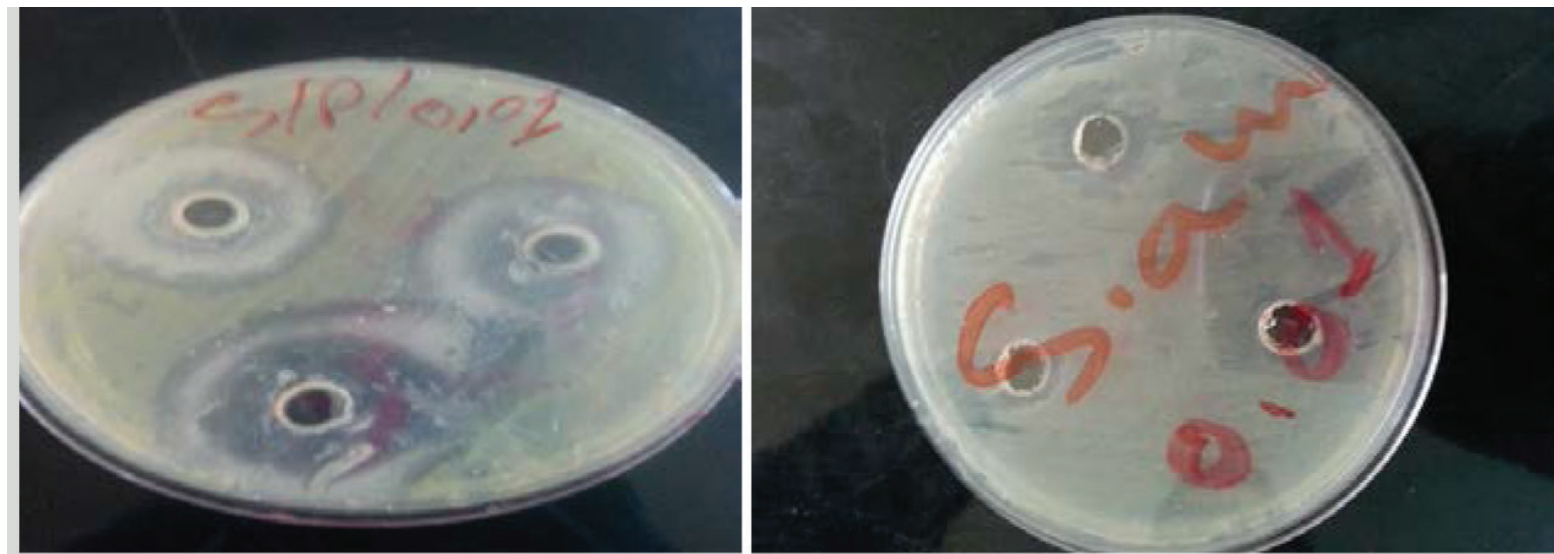

Fig. 5 S. aureus Drug conc. $10 \mathrm{mg} / \mathrm{ml}$, Plant conc. $10 \mathrm{mg} / \mathrm{ml}$.
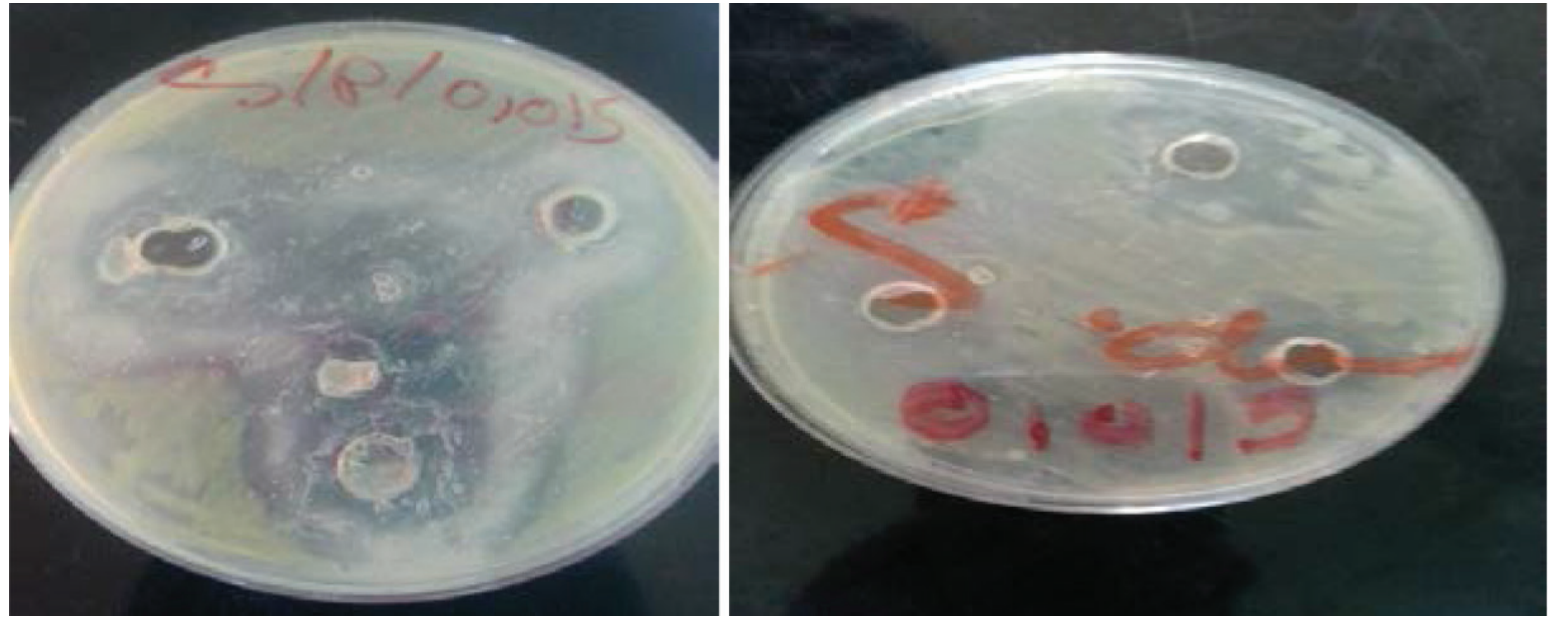

Fig. 6 S. aureus Drug conc. 15 mg/ml, Plant conc. $15 \mathrm{mg} / \mathrm{ml}$.
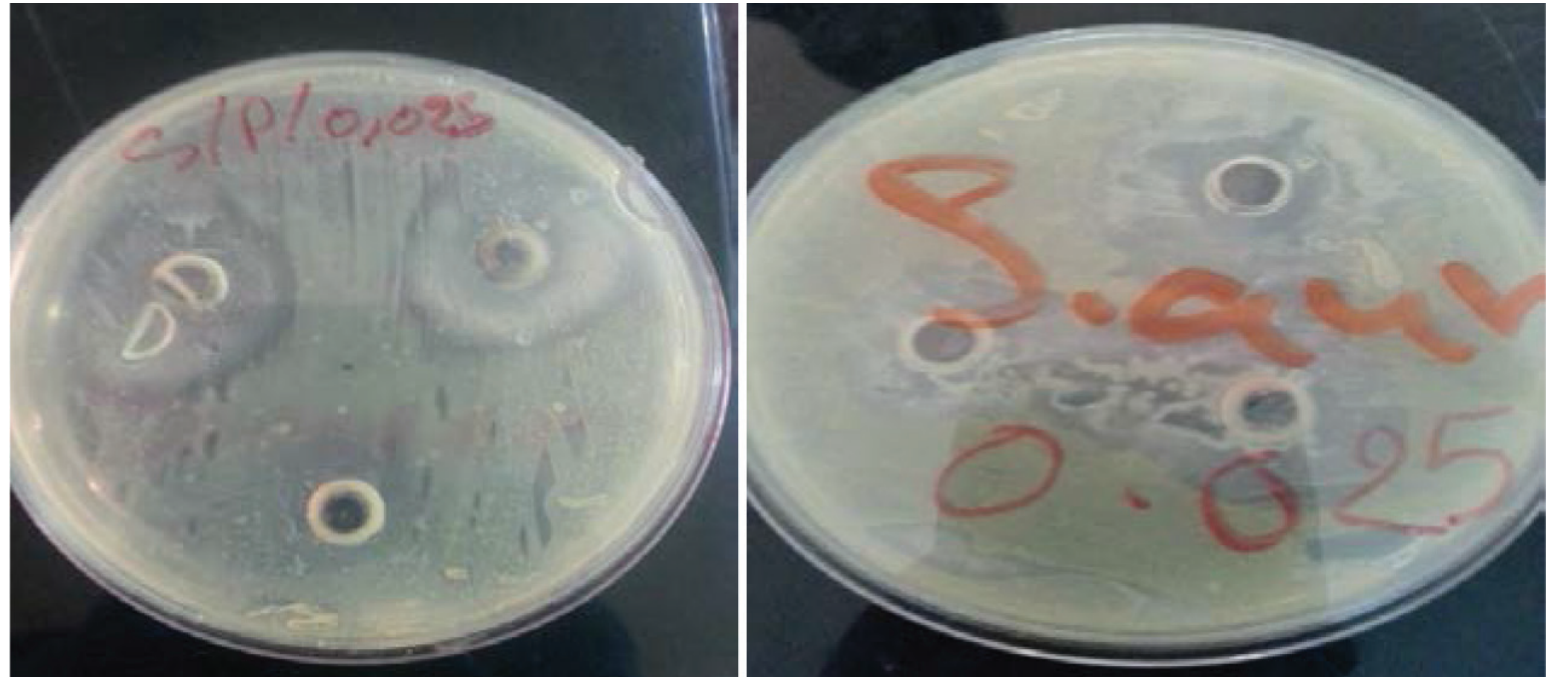

Fig. 7 S. aureus Drug conc. $25 \mathrm{mg} / \mathrm{ml}$, Plant conc. $25 \mathrm{mg} / \mathrm{ml}$.

significant activity against $S$. aureus $(40 \mathrm{~mm})$ and E. coli (35 $\mathrm{mm})$, leaf extract of Ocimum exhiple high activity against $E$. coli (34 mm), the methanol leaf extract of Acacia show significant activity against $E$. coli and $S$. aureus around $(15 \mathrm{~mm})$, dark extract of a Acacianilotica exhibit high activity against $S$. aureus $(15 \mathrm{~mm})$ and Sidacordifolia leaf extract possess maximum activity against $S$. aureus $(18 \mathrm{~mm})$ and Roots extract of extract plant showed high inhibitory action against $S$. aureus and least activity in E. coli. ${ }^{17}$ as well as, It was noted worthy that the lowest concentration of the leaf extract of $(50 \mathrm{mg} / \mathrm{ml})$ P. niruri was found to be very effective in inhibiting the growth of all the selected strains of $S$. aureus (3 strains), whereas, $P$. niruri has no inhibitory effect on the $E$. coli even at $400 \mathrm{mg} / \mathrm{ml}$, the fruit extracts of T. bellerica inhibited the growth of the $S$. aureus at 

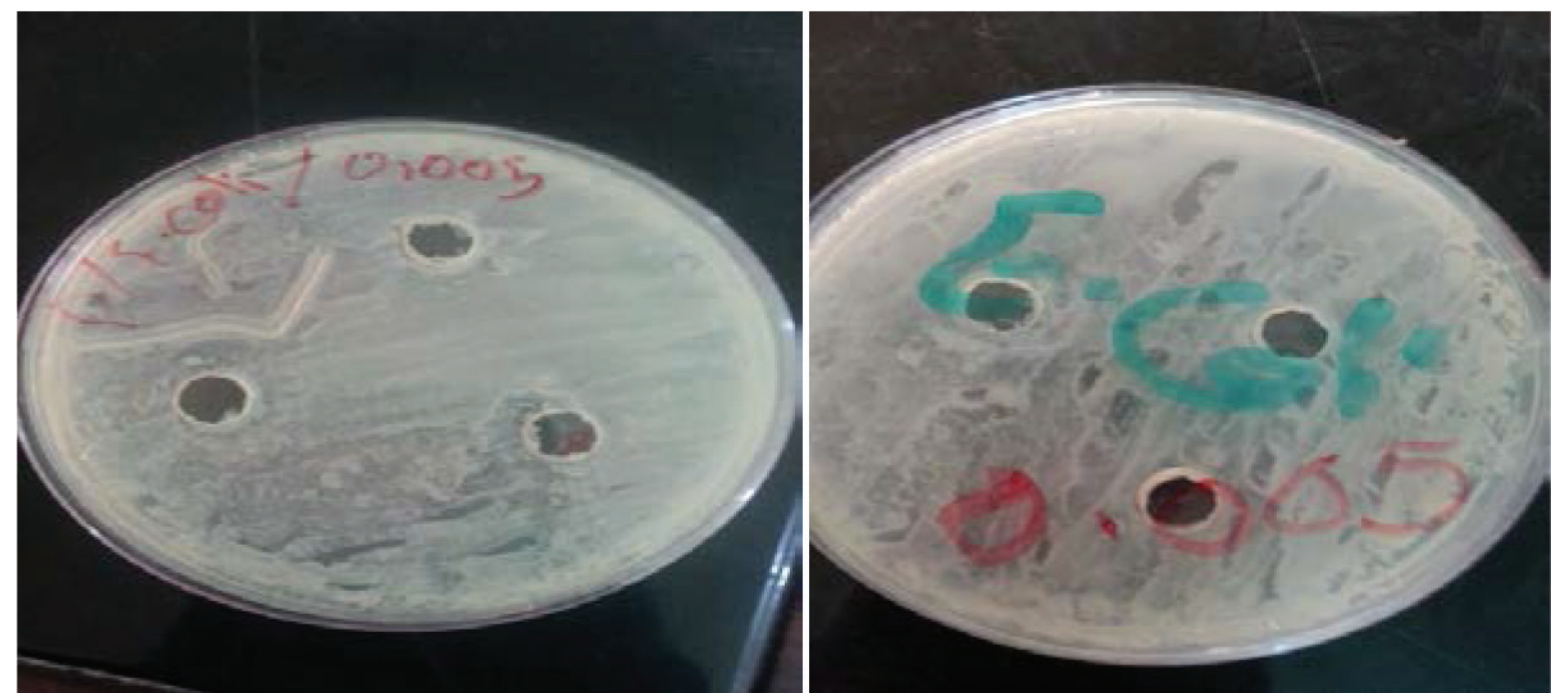

Fig. 8 E. coli Plant conc. $5 \mathrm{mg} / \mathrm{ml}$, Drug conc. $5 \mathrm{mg} / \mathrm{ml}$.

$(50 \mathrm{mg} / \mathrm{ml})$ and exhibited growth inhibition of E. coli at $(200$ $\mathrm{mg} / \mathrm{ml}$ ) only. ${ }^{18}$ Some study, the researcher is using many extracted plant of which C. arrensis; he was obtaining on result, when he used ethanol leave the inhibition zone is obtaining ( 8 $\mathrm{mm})$ to $E$. coli and $S$. aureus $(0 \mathrm{~mm})$, and used aqueous leave; the inhibition zone of E. coli $(3 \mathrm{~mm})$ and $S$. aureus $(0 \mathrm{~mm})$ and when he used ethanol seed; the inhibition zone of $E$. coli (2 $\mathrm{mm})$ and $S$. aureus $(2 \mathrm{~mm})$, also when he used aqueous seed; the inhibition zone of $E$. coli $(1 \mathrm{~mm})$ and $S$. aureus $(2 \mathrm{~mm}){ }^{19}$

\section{Conclusion}

The Cuscuta europaea extract plant have high antimicrobial activity on Staphylococcus aureus, the grude extract consider best than drug, The effect of extract on gram positive bacteria best from gram negative bacteria, The best concentration of extract on $S$. aureus is $20 \mathrm{mg} / \mathrm{ml}$.

\section{Recommendation}

The plant extract can be tested against all microorganisms (bacteria, fungi, etc.)

The active compound can be isolated and purified from the extract plant by applying various methodologies.

\section{Conflict of Interst}

None.

\section{References}

1. Brogden RN, Heel RC, Speight TM, Avery GS. Amoxicillin injectable: a review of its antibacterial spectrum, pharmacokinetics and therapeutic use. Drugs. 1979;18:169-184.

2. Ryan KJ, Ray CG. Sherris Medical Microbiology (4th ed.). McGraw Hill. ISBN 0-8385-8529-9, 2004

3. Harris LG, Foster SJ, Richards SG. An introduction to Staphylococcus aureus, and techniques for identifying and quantifying S. aureus adhesins in relation to adhesion to biomaterials: review. Eur Cells Mat. 2002:4:39-60.

4. Madigan M, Martinko J. Brock Biology of Microorganisms ( $11^{\text {th }}$ ed.). Prentice Hall. ISBN 0-13-144329-1, 2005.

5. http://www.health.state.mn.us/divs/idepc/disease laboratory-diagnosisfor-Staphylococcus aureus/.

6. Singleton P. Bacteria in Biology, Biotechnology and Medicine ( $5^{\text {th }}$ ed.). Wiley 1999:444-454. ISBN 0-471-98880-4

7. Bruix J, Raoul JL. Infection of Escherichia coli CDC National Center for Emerging and zoonotic infectious Diseases. Retrieved 2012-10-02.

8. Vogt RL, Dippold L. Escherichia coli 0157:H7 outbreak associated with consumption of ground beef, June-July 2002. Public Health Reports. 2005;120:174-178.

9. Bentley R, Meganathan R. Biosynthesis of vitamin K (menaquinone) in bacteria. Microbiol Rev. 1982;46:241-280.

10. Hudault S, Guignot J, Servin AL. Escherichia coli strains colonizing the gastrointestinal tract protect germ free mice against Salmonella typhimurium infection. Gut. 2001;49:47-55.

11. Reid G, Howard J, Gan BS. Can bacterial interference prevent infection? Trends Microbiol. 2001;9:424-428.

12. Russell JB, Jarvis GN. Practical mechanisms for interrupting the oral-fecal lifecycle of Escherichai coli. J Mol Microbiol Biotechnol. 2001;3:265-272.

13. http://en.wikipedia.org/wiki/natural_products (accessed 3 March 2009).

14. Geller NL. Advances in Clinical Trial Biostatistics Marylwed. 3ed. USA. 66. 2004.

15. Faiyyaz I, Rajesh O, Trushal C, Kapil G. In vitro antimicrobial activity of Cuscuta Reflexa Roxb. Int Res J Pharm. 2011;2:214-216.

16. Raza M, Rahman A, Wahab A, Iqbal H, Ullah, H, Ahmed S, et al. Comparative antibacterial study of Convolvulus arvensis collected from different areas of Khyber pakhtunkhwa, Pakistan. J Pharm. 2012;3:220-222.

17. Govindarajan R, Vijayakumar M, Singh M, Rao CHV, Shirwaikar A, Rawat AKS, et al. Antiulcer and antimicrobial activity of Anogeissus latifolia. J Ethnopharmacol. 2006;106:57-61.

18. Stary F, Hans S. The National guide to medical herbs and plant. Tiger Books Int. Plc. UK, 1998.

19. Cheng H, Qin ZH, Guo XF, Hu XS, Wu JH. Geographical origin identification of propolis using GC-MS and electronic nose combined with principal component analysis. Ann Biol Res. 2013;4(8):35 